\title{
Pedobacter rhizosphaerae sp. nov. and Pedobacter soli sp. nov., isolated from rhizosphere soil of Chinese cabbage (Brassica campestris)
}

\begin{abstract}
Correspondence
Hang-Yeon Weon

hyweon@rda.go.kr
\end{abstract}

\author{
Soon-Wo Kwon, Jung-A Son, Soo-Jin Kim, Yi-Seul Kim, In-Cheol Park, \\ Jeung-Im Bok and Hang-Yeon Weon
}

\author{
Agricultural Microbiology Team, National Academy of Agricultural Science, \\ Rural Development Administration, Suwon 441-707, Republic of Korea
}

The genus Pedobacter was proposed by Steyn et al. (1998) on the basis of the classification of heparinolytic bacteria, with the description of the type species (Pedobacter heparinus) and three others. Since the description of Pedobacter cryoconitis by Margesin et al. (2003), the number of recognized species has increased tremendously, with 27 novel species described up to 2010. This number reflects the easy recovery of members of the genus from the natural environment; species of the genus have been isolated from terrestrial environments (mainly soil and water) by using common media such as trypticase soy agar (TSA) or R2A agar. The genus Pedobacter includes Gram-negative, aerophilic or microaerophilic bacteria that are able to grow at $1-45{ }^{\circ} \mathrm{C}$. Colonies exhibit various colours from yellow to white or pink (Gallego et al., 2006), but the pigment does not exhibit the typical flexirubin reaction. Chemotaxonomically, members of the genus contain menaquinone-7 (MK-7) as the predominant menaquinone. They contain iso- $\mathrm{C}_{17: 0} 3-\mathrm{OH}$, iso- $\mathrm{C}_{15: 0}$ and summed feature 3 (iso- $\mathrm{C}_{15: 0} 2-\mathrm{OH}$ and/or $\mathrm{C}_{16: 1} \omega 7 c$ ) as major fatty acids and have genomic DNA G $+\mathrm{C}$ contents of $33.8-44.2 \mathrm{~mol} \%$. In

The GenBank/EMBL/DDBJ accession numbers for the $16 \mathrm{~S}$ rRNA gene sequences of strains $01-96^{\top}$ and $15-51^{\top}$ are AM279214 and AM279215, respectively. this study, we characterized taxonomically two Pedobacterlike bacterial strains.

Two pink-coloured strains, designated $01-96^{\mathrm{T}}$ and $15-51^{\mathrm{T}}$, were isolated from rhizosphere soil of Chinese cabbage (Brassica campestris L.) grown in lysimeters $\left(37^{\circ} 16^{\prime} 38.50^{\prime \prime} \mathrm{N}\right.$ $126^{\circ} 58^{\prime} 59.60^{\prime \prime} \mathrm{E}$ ), which had been in continuous operation since 1994 in the National Academy of Agricultural Science. Rhizosphere soil samples were collected from the root surface. The soil samples had the following chemical properties: $\mathrm{pH}$, 6.6; total organic carbon, $23 \mathrm{~g} \mathrm{~kg}^{-1}$; available $\mathrm{P}_{2} \mathrm{O}_{5}$, $1184 \mathrm{mg} \mathrm{kg}^{-1}$; exchangeable $\mathrm{K}, 0.45 \mathrm{cmol} \mathrm{kg}^{-1}$; exchangeable $\mathrm{Ca}, 2.5 \mathrm{cmol} \mathrm{kg}^{-1}$; exchangeable $\mathrm{Mg}, 1.5 \mathrm{cmol} \mathrm{kg}^{-1}$. The soil texture was sandy loam. After sampling, $10 \mathrm{~g}$ rhizosphere soil was suspended in $90 \mathrm{ml}$ distilled water containing $0.85 \% \mathrm{NaCl}(\mathrm{w} / \mathrm{v})$, and serially diluted and plated on TSA. After incubation for 5 days at $28{ }^{\circ} \mathrm{C}$, strains $01-96^{\mathrm{T}}$ and $15-51^{\mathrm{T}}$ were recovered and routine cultivation was conducted at $28{ }^{\circ} \mathrm{C}$ on TSA. Seven reference type strains of recognized Pedobacter species were obtained from the Korean Agricultural Culture Collection (KACC) for comparison of phenotypic and chemotaxonomic characteristics, namely Pedobacter agri KACC $14024^{\mathrm{T}}$, P. alluvionis KACC $14286^{\mathrm{T}}, P$. borealis KACC $14287^{\mathrm{T}}$, P. roseus KACC $11594^{\mathrm{T}}$, P. sandarakinus KACC $11593^{\mathrm{T}}$, P. suwonensis KACC $11317^{\mathrm{T}}$ and $P$. terrae KACC $13760^{\mathrm{T}}$. 
Growth was tested on Luria-Bertani (LB) agar, nutrient agar (NA), R2A agar and MacConkey agar (all from Difco). Phenotypic characteristics, including Gram-staining, catalase and oxidase activity and hydrolysis of CM-cellulose $(0.1 \%$, $\mathrm{w} / \mathrm{v})$, casein $(10 \%$ skimmed milk, w/v), chitin $(0.5 \%, \mathrm{w} / \mathrm{v})$, hypoxanthine $(0.5 \%, \mathrm{w} / \mathrm{v})$, tyrosine $(0.5 \%, \mathrm{w} / \mathrm{v})$, Tween 80 $(1.0 \%, \mathrm{v} / \mathrm{v})$, starch $(1.0 \%, \mathrm{w} / \mathrm{v})$ and xanthine $(0.5 \%, \mathrm{w} / \mathrm{v})$, were determined by using the methods of Smibert \& Krieg (1994). Growth under anaerobic conditions was tested in a GasPak (BBL) jar at $28{ }^{\circ} \mathrm{C}$ for 14 days. Heparinase production was determined by the method of Joubert $e t$ al. (1984). Flexirubin pigments were investigated by suspending cells in $20 \% \mathrm{KOH}$ (Fautz \& Reichenbach, 1980). Growth at $\mathrm{pH} 4.0-10.0$ (at intervals of $0.5 \mathrm{pH}$ units) was determined in TSA broth (TSB) that was buffered with citrate/phosphate buffer or Tris/HCl (Breznak \& Costilow, 1994). Growth in the presence of $0.5,1.0,1.5,2.0,3.0$ and $5.0 \%(\mathrm{w} / \mathrm{v}) \mathrm{NaCl}$, and at $10,15,20,25,30,35,37$ and $40{ }^{\circ} \mathrm{C}$ was investigated on TSA. Growth at $1-5{ }^{\circ} \mathrm{C}$ was also tested on TSA slants by using a bench-top incubator (e-CoolingBucket ECB; Taitec). Carbon assimilation was tested by using the API $50 \mathrm{CH}$ gallery as described by Kersters et al. (1984). Tests in the API 20E and API ZYM (bioMérieux) commercial systems were performed according to the manufacturer's instructions. API ZYM test strips were read after $4 \mathrm{~h}$ incubation at $37^{\circ} \mathrm{C}$, whilst API 20E strips were examined after 7 days at $28{ }^{\circ} \mathrm{C}$. Cell morphology was observed by transmission electron microscopy (912AB; LEO) and phase-contrast microscopy (AXIO; Zeiss) by using cells grown on TSA. Motility was tested by the hanging-drop method (Skerman, 1967) with phase-contrast microscopy. Strains $01-96^{\mathrm{T}}$ and $15-51^{\mathrm{T}}$ grew on LB agar, NA, R2A agar and TSA, but not on MacConkey agar. Detailed characteristics for the two strains are provided in the species descriptions, and the characteristics that differentiate these strains from related type strains are summarized in Table 1.

Fatty acid methyl esters were extracted and prepared by using the standard protocol of the Microbial Identification System (MIDI, 1999) after cells were grown on TSA for 2 days at $28{ }^{\circ} \mathrm{C}$. Isoprenoid quinones were analysed by HPLC as described by Groth et al. (1996). The DNA G + C content was determined by HPLC analysis of deoxyribonucleosides as described by Mesbah et al. (1989) by using a reversed-phase column (Supelcosil LC-18 S; Supelco). Strains $01-96^{\mathrm{T}}$ and $15-51^{\mathrm{T}}$ contained $\mathrm{C}_{18: 1} \omega 7 c$ and summed feature 3 (comprising $\mathrm{C}_{16: 1} \omega 7 c$ and/or iso- $\mathrm{C}_{15: 0} 2-\mathrm{OH}$ ) as major fatty acids (Table 2). The fatty acid profiles of the two novel strains were similar to those of their closest phylogenetic neighbours, i.e. members of the genus Pedobacter, quantitative differences between these two strains and their closest phylogenetic neighbours are detailed in Table 2. The predominant menaquinone of the two strains was menaquinone-7 (MK7), consistent with data for the reference Pedobacter species. The DNA G $+\mathrm{C}$ contents of strains $01-96^{\mathrm{T}}$ and $15-51^{\mathrm{T}}$ were 37.8 and $38.6 \mathrm{~mol} \%$, respectively; these values were within the range $(33.8-44.2 \mathrm{~mol} \%)$ reported for members of the genus Pedobacter.
The 16S rRNA gene sequences of the two strains were determined by PCR amplification (Kwon et al., 2003) and direct sequencing (Hiraishi, 1992). Nearly complete 16S rRNA gene sequences were determined for strains $01-96^{\mathrm{T}}$ (1486 bp) and $15-51^{\mathrm{T}}(1487 \mathrm{bp})$. Identification of phylogenetic neighbours and calculation of pairwise levels of $16 \mathrm{~S}$ rRNA gene sequence similarity were achieved by using the EzTaxon server (http://www.eztaxon.org/; Chun et al., 2007). The program CLUSTAL $\mathrm{W}$ version 1.8 (Thompson et al., 1994) was used to align the sequences of strains $01-96^{\mathrm{T}}$ and $15-51^{\mathrm{T}}$ with those of related taxa retrieved from public databases. Phylogenetic analysis was performed via the software package MEGA version 4.1 (Tamura et al., 2007), by using the neighbour-joining (Saitou \& Nei, 1987) and maximum-parsimony (Fitch, 1971) methods with bootstrap values based on 1000 replications (Felsenstein, 1985). To determine genomic relatedness, the filter hybridization method was performed according to Seldin \& Dubnau (1985). Probe labelling was conducted by using the nonradioactive DIG-High prime system (Roche); hybridized DNA was visualized with the DIG luminescent detection kit (Roche). Levels of DNA-DNA relatedness were quantified by using Bio-1D Image analysis software (Vilber Lourmat). The neighbour-joining phylogenetic tree based on $16 \mathrm{~S}$ rRNA gene sequences revealed that strains $01-96^{\mathrm{T}}$ and $15-51^{\mathrm{T}}$ were members of the family Sphingobacteriaceae of the phylum Bacteroidetes. The two strains formed a cluster (bootstrap value $83 \%$ ) with $P$. agri $\mathrm{PB} 92^{\mathrm{T}}, P$. alluvionis NWER-II1 $1^{\mathrm{T}}, P$. borealis $\mathrm{G}-1^{\mathrm{T}}, P$. roseus $\mathrm{CL}-\mathrm{GP} 80^{\mathrm{T}}, P$. sandarakinus $\mathrm{DS}-27^{\mathrm{T}}$, P. suwonensis $15-52^{\mathrm{T}}$ and P. terrae DS- $57^{\mathrm{T}}$ (Fig. 1). Similar results were also obtained with the maximum-parsimony algorithm. Levels of $16 \mathrm{~S}$ rRNA gene sequence similarity between strain $01-96^{\mathrm{T}}$ and the type strains of all recognized Pedobacter species were $<96.7 \%$, whereas levels of similarity between strain $15-51^{\mathrm{T}}$ and $P$. borealis $\mathrm{G}-1^{\mathrm{T}}$ and P. suwonensis $15-52^{\mathrm{T}}$ were 97.2 and $97.1 \%$, respectively. $16 \mathrm{~S}$ rRNA gene sequence similarity between strains $01-96^{\mathrm{T}}$ and $15-51^{\mathrm{T}}$ was $96.2 \%$.

To clarify the taxonomic position of strain $15-51^{\mathrm{T}}$ at the species level, DNA-DNA hybridization was performed. Levels of DNA-DNA relatedness between strain $15-51^{\mathrm{T}}$ and P. suwonensis KACC $11317^{\mathrm{T}}$ and P. borealis KACC $14287^{\mathrm{T}}$ were $49.4 \%$ (reciprocal, $45.2 \%$ ) and $40.9 \%$ (reciprocal, $30.2 \%$ ), respectively. The $16 \mathrm{~S}$ rRNA gene-based phylogeny and DNA-DNA hybridization results thus revealed that strains $01-96^{\mathrm{T}}$ and $15-51^{\mathrm{T}}$ could be classified as novel members of the genus Pedobacter. Strains $01-96^{\mathrm{T}}$ and $15-51^{\mathrm{T}}$ were found to share many physiological and morphological characteristics with each other. However, they could be differentiated from each other on the basis of their DNA $\mathrm{G}+\mathrm{C}$ content, assimilation patterns of five carbon sources and temperature ranges for growth (Table 1). Strains 01-96 ${ }^{\mathrm{T}}$ and $15-51^{\mathrm{T}}$ could be differentiated from their phylogenetically closest relatives based on hydrolysis of casein, CMcellulose and gelatin, assimilation patterns and enzyme activities (API ZYM). On the basis of data from the present polyphasic taxonomic study, strains $01-96^{\mathrm{T}}$ and $15-51^{\mathrm{T}}$ are 
Table 1. Differential phenotypic characteristics between strains $01-96^{\top}$ and $15-51^{\top}$ and the type strains of closely related Pedobacter species

Strains: $1,01-96^{\mathrm{T}} ; 2,15-51^{\mathrm{T}}$; 3, P. agri KACC $14024^{\mathrm{T}}$; 4, P. alluvionis KACC $14286^{\mathrm{T}} ; 5$, P. borealis KACC $14287^{\mathrm{T}}$; 6, P. roseus $\mathrm{KACC}_{11594^{\mathrm{T}}}$; 7 , P. sandarakinus KACC $11593^{\mathrm{T}}$; 8, P. suwonensis KACC $11317^{\mathrm{T}}$; 9, P. terrae KACC $13760^{\mathrm{T}}$. Unless otherwise indicated, data for reference type strains were compiled from Gordon et al. (2009), Hwang et al. (2006), Kwon et al. (2007), Roh et al. (2008) and Yoon et al. (2006, 2007). All strains are positive for aerobic growth, hydrolysis of starch, tyrosine and Tween 80, assimilation of D-xylose, galactose, glucose, mannose, methyl $\alpha$-D-glucoside, $N$ acetylglucosamine, arbutin, aesculin, salicin, cellobiose, maltose, lactose, melibiose, sucrose, trehalose, starch, gentiobiose and turanose and enzyme activities of catalase, oxidase, alkaline phosphatase, esterase (C4), esterase lipase (C8), leucine arylamidase, acid phosphatase, naphthol-AS-BIphosphohydrolase and $\alpha$-glucosidase, but negative for assimilation of glycerol, erythritol, ribose, L-xylose, sorbose, inositol, mannitol, D-tagatose, D- and L-arabitol and 2-ketogluconate and enzyme activities of lipase (C14) and $\alpha$-chymotrypsin. + , Positive; (+), weakly positive; v, variable; - , negative.

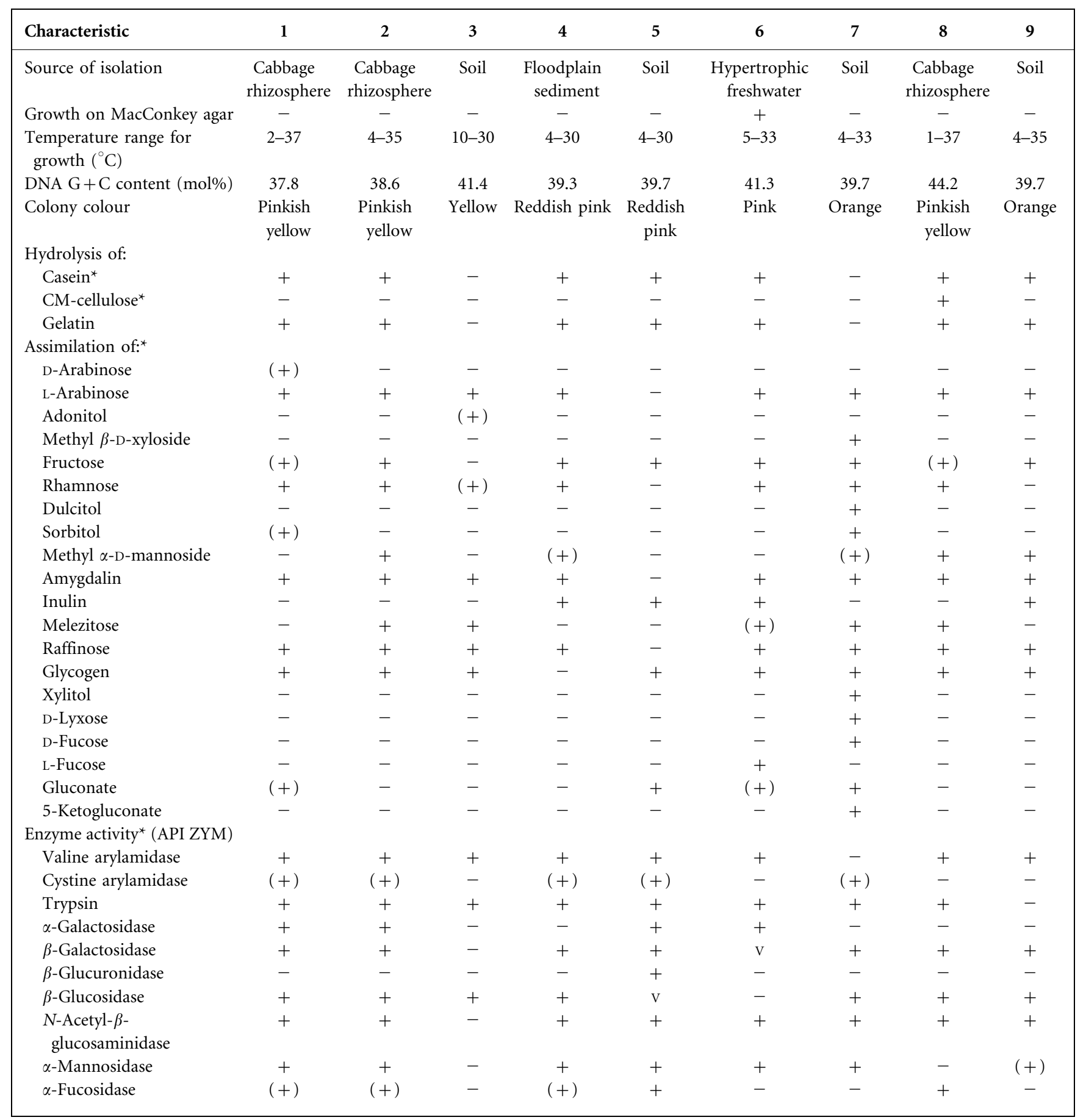

${ }^{\star}$ Data from this study except those for P. suwonensis KACC $11317^{\mathrm{T}}$. 
Table 2. Cellular fatty acid profiles of strains $01-96^{\top}$ and $15-51^{\top}$ and the type strains of related Pedobacter species

Strains: $1,01-96^{\mathrm{T}} ; 2,15-51^{\mathrm{T}}$; 3, P. agri KACC $14024^{\mathrm{T}} ; 4$, P. alluvionis KACC $14286^{\mathrm{T}} ; 5$, P. borealis KACC $14287^{\mathrm{T}}$; 6, P. roseus KACC $11594^{\mathrm{T}}$; 7 , P. sandarakinus KACC $11593^{\mathrm{T}}$; 8, P. suwonensis KACC $11317^{\mathrm{T}}$; 9, P. terrae KACC $13760^{\mathrm{T}}$. Data were obtained in this study except those for $P$. suwonensis KACC $11317^{\mathrm{T}}$, which was taken from Kwon et al. (2007). Prior to fatty acid extraction, all strains were grown on TSA (Difco) at $28{ }^{\circ} \mathrm{C}$ for 2 days. Values are percentages of the total fatty acids, and only fatty acids representing more than $1 \%$ for at least one of the strains are shown. - , Not detected; tr, trace amounts $(<1 \%)$.

\begin{tabular}{|c|c|c|c|c|c|c|c|c|c|}
\hline Fatty acid & 1 & 2 & 3 & 4 & 4 & 6 & 7 & 8 & 9 \\
\hline \multicolumn{10}{|c|}{ Straight-chain saturated } \\
\hline $\mathrm{C}_{14: 0}$ & $\operatorname{tr}$ & $\operatorname{tr}$ & 1.8 & $\operatorname{tr}$ & 1.0 & $\operatorname{tr}$ & $\operatorname{tr}$ & $\operatorname{tr}$ & $\operatorname{tr}$ \\
\hline $\mathrm{C}_{14: 0} 2-\mathrm{OH}$ & $\operatorname{tr}$ & $\operatorname{tr}$ & 1.0 & $\operatorname{tr}$ & $\operatorname{tr}$ & $\operatorname{tr}$ & - & - & $\operatorname{tr}$ \\
\hline $\mathrm{C}_{16: 0} 3-\mathrm{OH}$ & 3.1 & 2.1 & 4.7 & 2.0 & 2.2 & 1.7 & 1.1 & $\operatorname{tr}$ & 1.1 \\
\hline $\mathrm{C}_{17: 0} 2-\mathrm{OH}$ & $\operatorname{tr}$ & $\operatorname{tr}$ & $\operatorname{tr}$ & $\operatorname{tr}$ & $\operatorname{tr}$ & 1.0 & $\operatorname{tr}$ & - & $\operatorname{tr}$ \\
\hline $\mathrm{C}_{15: 1} \omega 6 c$ & $\operatorname{tr}$ & $\operatorname{tr}$ & $\operatorname{tr}$ & $\operatorname{tr}$ & $\operatorname{tr}$ & $\operatorname{tr}$ & 1.5 & - & $\operatorname{tr}$ \\
\hline $\mathrm{C}_{16: 1} \omega 5 c$ & 2.1 & 1.4 & 3.5 & 2.0 & 2.7 & 1.4 & 1.4 & 1.4 & 1.5 \\
\hline $\mathrm{C}_{17: 1} \omega 8 c$ & $\operatorname{tr}$ & - & $\operatorname{tr}$ & - & - & - & 1.0 & - & - \\
\hline $\mathrm{C}_{18: 1} \omega 5 c$ & $\operatorname{tr}$ & $\operatorname{tr}$ & - & $\operatorname{tr}$ & 1.3 & $\operatorname{tr}$ & $\operatorname{tr}$ & $\operatorname{tr}$ & $\operatorname{tr}$ \\
\hline iso- $\mathrm{C}_{17: 1} \omega 9 c$ & 5.1 & 6.9 & 1.3 & 4.3 & 6.6 & 5.9 & 3.8 & 7.4 & 7.1 \\
\hline \multicolumn{10}{|c|}{ Branched saturated } \\
\hline iso- $\mathrm{C}_{15: 0} 3-\mathrm{OH}$ & 2.5 & 2.0 & 2.0 & 3.5 & 3.3 & 2.5 & 3.3 & 2.4 & 2.9 \\
\hline iso- $\mathrm{C}_{16: 0} 3-\mathrm{OH}$ & $\operatorname{tr}$ & $\operatorname{tr}$ & 1.4 & $\operatorname{tr}$ & $\operatorname{tr}$ & $\operatorname{tr}$ & $\operatorname{tr}$ & $\operatorname{tr}$ & $\operatorname{tr}$ \\
\hline iso- $\mathrm{C}_{17: 0} 3-\mathrm{OH}$ & 15.7 & 12.3 & 10.7 & 14.6 & 14.6 & 16.4 & 18.0 & 15.8 & 17.0 \\
\hline \multicolumn{10}{|c|}{ Summed features ${ }^{\star}$} \\
\hline 1 & $\operatorname{tr}$ & $\operatorname{tr}$ & $\operatorname{tr}$ & $\operatorname{tr}$ & 1.1 & $\operatorname{tr}$ & $\operatorname{tr}$ & $\operatorname{tr}$ & $\operatorname{tr}$ \\
\hline 3 & 28.6 & 33.1 & 35.2 & 30.4 & 30.6 & 26.8 & 22.9 & 27.2 & 29.8 \\
\hline 4 & 1.7 & 1.0 & - & 3.5 & 2.3 & $\operatorname{tr}$ & - & $\operatorname{tr}$ & 1.2 \\
\hline \multicolumn{10}{|c|}{ Unknown fatty acids $\dagger$} \\
\hline ECL 13.565 & $\operatorname{tr}$ & $\operatorname{tr}$ & $\operatorname{tr}$ & $\operatorname{tr}$ & $\operatorname{tr}$ & $\operatorname{tr}$ & $\operatorname{tr}$ & 1.3 & $\operatorname{tr}$ \\
\hline ECL 16.582 & 1.5 & 1.3 & 1.2 & 1.1 & 1.3 & 1.3 & 1.6 & 1.5 & 1.0 \\
\hline
\end{tabular}

${ }^{*}$ Summed feature 1 comprises $\mathrm{C}_{13: 0} 3-\mathrm{OH}$ and/or iso- $\mathrm{C}_{15: 1} \mathrm{I}$, summed feature 3 comprises iso- $\mathrm{C}_{15: 0} 2-\mathrm{OH}$ and/or $\mathrm{C}_{16: 1} \omega 7 c$ and summed feature 4 comprises anteiso- $\mathrm{C}_{17: 1} \mathrm{~B}$ and/or iso- $\mathrm{C}_{17: 1} \mathrm{I}$.

$\nmid$ Unknown fatty acids have no name listed in the peak library file of the MIDI system and therefore cannot be identified; equivalent chain-lengths are given.

thus considered to represent novel species of the genus Pedobacter, for which the names Pedobacter rhizosphaerae sp. nov. and Pedobacter soli sp. nov. are proposed, respectively.

\section{Description of Pedobacter rhizosphaerae sp. nov.}

Pedobacter rhizosphaerae [rhi.zo.sphae' rae. Gr. fem. n. rhiza root; L. fem. n. sphaera-ae (from Gr. fem. n. sphaira-as) ball, any globe, sphere; N.L. gen. fem. n. rhizosphaerae of the rhizosphere].

Cells are strictly aerobic, Gram-stain-negative, non-motile, non-spore-forming rods, $0.7-0.8 \mu \mathrm{m}$ in diameter and $1.4-$ $2.2 \mu \mathrm{m}$ long after 2 days at $28{ }^{\circ} \mathrm{C}$ on TSA. Colonies are $0.4-$ $1.0 \mathrm{~mm}$ in diameter, smooth, circular, convex and pink after 2 days at $28{ }^{\circ} \mathrm{C}$ on TSA. Grows on LB agar, NA, R2A agar and TSA, but not on MacConkey agar. Catalase- and oxidase-positive. Growth occurs at $2-37{ }^{\circ} \mathrm{C}$, at pH 5.5-8.0 and with $\mathrm{NaCl}$ concentrations of $0-1.5 \%$. Hydrolyses casein, gelatin, starch, tyrosine and Tween 80 , but not chitin, CMcellulose, heparin, hypoxanthine, urea or xanthine. Positive (in API ZYM strips) for alkaline phosphatase, esterase (C4), esterase lipase (C8), leucine arylamidase, valine arylamidase, cystine arylamidase, trypsin, acid phosphatase, naphtholAS-BI-phosphohydrolase, $\alpha$-galactosidase, $\beta$-galactosidase, $\alpha$-glucosidase, $\beta$-glucosidase, $N$-acetyl- $\beta$-glucosaminidase, $\alpha$-mannosidase and $\alpha$-fucosidase, but negative for lipase (C14), $\alpha$-chymotrypsin and $\beta$-glucuronidase activities. Assimilates D- and L-arabinose, D-xylose, galactose, glucose, fructose, mannose, rhamnose, sorbitol, methyl $\alpha$-D-glucoside, $\mathrm{N}$-acetylglucosamine, amygdalin, aesculin, salicin, cellobiose, maltose, lactose, melibiose, sucrose, trehalose, raffinose, starch, glycogen, gentiobiose, turanose and gluconate, but 


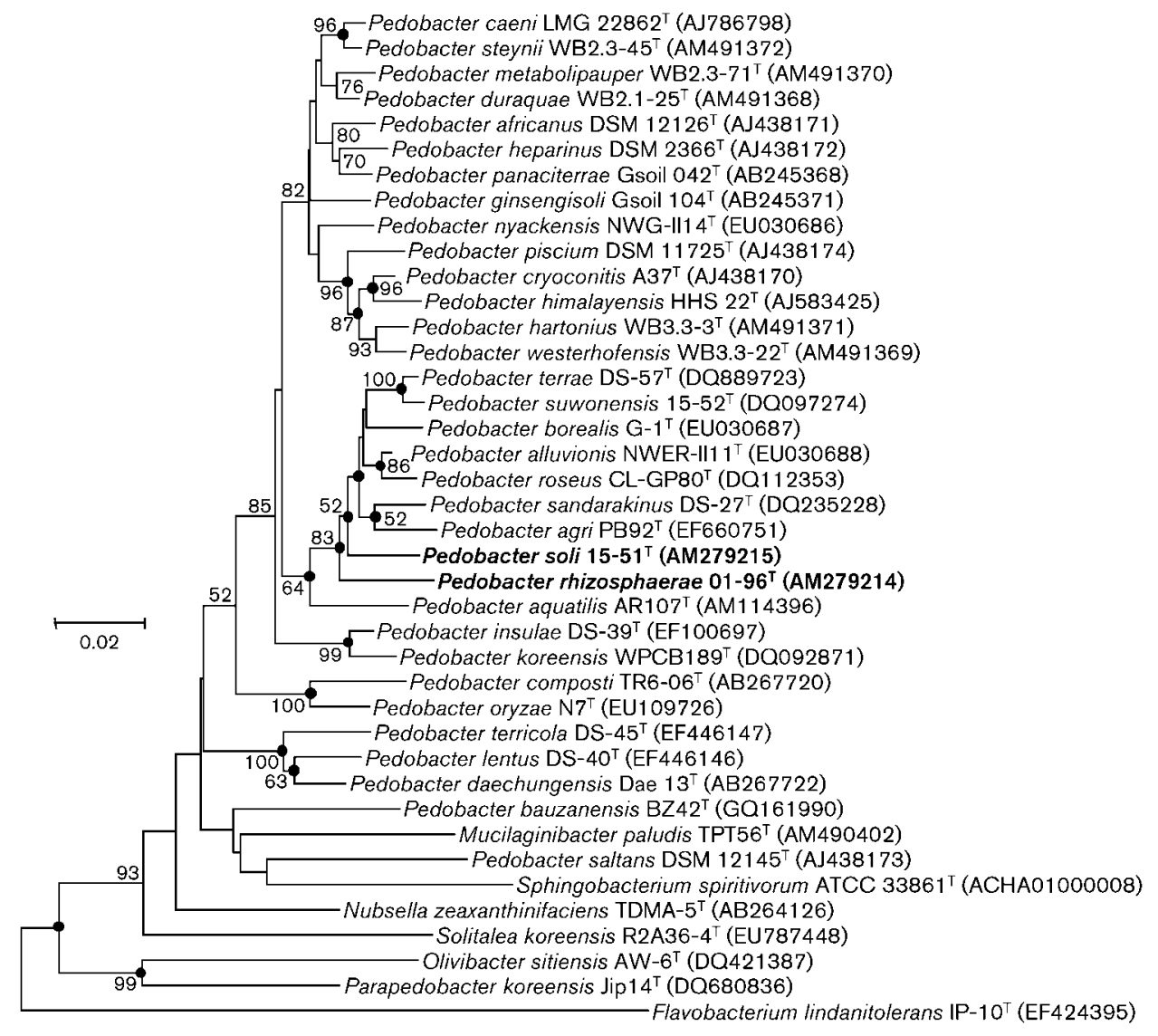

Fig. 1. Neighbour-joining phylogenetic dendrogram constructed from a comparative analysis of $16 \mathrm{~S}$ rRNA gene sequences showing the relationships between strains $01-96^{\top}$ and $15-51^{\top}$ and related species. Bootstrap values (expressed as percentages of 1000 replications) of $>50 \%$ are shown at branch points. Filled circles indicate that the corresponding branches were also recovered in the maximum-parsimony tree. Bar, 2 substitutions per 100 nucleotide positions.

not glycerol, erythritol, ribose, L-xylose, adonitol, methyl $\beta$-Dxyloside, sorbose, dulcitol, inositol, mannitol, methyl $\alpha$-Dmannoside, inulin, melezitose, xylitol, D-lyxose, D-tagatose, D- or L-fucose, D- or L-arabitol or 2- or 5-ketogluconate. The predominant menaquinone is MK-7. The major fatty acids are iso- $\mathrm{C}_{17: 0} 3-\mathrm{OH}$, iso- $\mathrm{C}_{15: 0}$ and summed feature 3 (iso$\mathrm{C}_{15: 0} 2-\mathrm{OH}$ and/or $\left.\mathrm{C}_{16: 1} \omega 7 c\right)$. The DNA G $+\mathrm{C}$ content of the type strain is $37.8 \mathrm{~mol} \%$.

The type strain, $01-96^{\mathrm{T}}\left(=\right.$ KACC $14938^{\mathrm{T}}=$ NBRC $\left.107690^{\mathrm{T}}\right)$, was isolated from the rhizosphere of Chinese cabbage (Brassica campestris L.).

\section{Description of Pedobacter soli sp. nov.}

Pedobacter soli (so'li. L. gen. n. soli of soil, the source of the type strain).

Cells are strictly aerobic, Gram-stain-negative, non-motile, non-spore-forming rods, $0.7-0.8 \mu \mathrm{m}$ in diameter and 1.4$3.0 \mu \mathrm{m}$ long after 2 days at $28{ }^{\circ} \mathrm{C}$ on TSA. Colonies are $0.4-$ $0.5 \mathrm{~mm}$ in diameter, smooth, circular, convex and pink after 2 days at $28{ }^{\circ} \mathrm{C}$ on TSA. Grows on LB agar, NA, R2A agar and TSA, but not on MacConkey agar. Catalase- and oxidase-positive. Growth occurs at $4-35{ }^{\circ} \mathrm{C}$, at $\mathrm{pH}$ 5.5-8.0 and with $\mathrm{NaCl}$ concentrations of $0-1.5 \%$. Hydrolyses casein, gelatin, starch, tyrosine and Tween 80 , but not chitin, CM-cellulose, heparin, hypoxanthine, urea or xanthine. Positive (in API ZYM strips) for alkaline phosphatase, esterase $(\mathrm{C} 4)$, esterase lipase (C8), leucine arylamidase, valine arylamidase, cystine arylamidase, trypsin, acid phosphatase, naphthol-AS-BI-phosphohydrolase, $\alpha$-galactosidase, $\beta$-galactosidase, $\alpha$-glucosidase, $\beta$-glucosidase, $N$-acetyl- $\beta$-glucosaminidase, $\alpha$-mannosidase and $\alpha$ fucosidase, but negative for lipase (C14), $\alpha$-chymotrypsin and $\beta$-glucuronidase activities. Assimilates L-arabinose, Dxylose, galactose, glucose, fructose, mannose, rhamnose, methyl $\alpha$-D-mannoside, methyl $\alpha$-D-glucoside, $N$-acetylglucosamine, amygdalin, arbutin, aesculin, salicin, cellobiose, maltose, lactose, melibiose, sucrose, trehalose, melezitose, raffinose, starch, glycogen, gentiobiose and turanose, but not glycerol, erythritol, D-arabinose, ribose, L-xylose, adonitol, methyl $\beta$-D-xyloside, sorbose, dulcitol, inositol, mannitol, sorbitol, inulin, xylitol, D-lyxose, D-tagatose, D- or L-fucose, D- or L-arabitol, gluconate or 2- or 5-ketogluconate. The 
predominant menaquinone is MK-7. The major fatty acids are iso- $\mathrm{C}_{17: 0} 3-\mathrm{OH}$, iso- $\mathrm{C}_{15: 0}$ and summed feature 3 (iso$\mathrm{C}_{15: 0} 2-\mathrm{OH}$ and/or $\left.\mathrm{C}_{16: 1} \omega 7 c\right)$. The DNA G $+\mathrm{C}$ content of the type strain is $38.6 \mathrm{~mol} \%$.

The type strain, $15-51^{\mathrm{T}}\left(=\right.$ KACC $14939^{\mathrm{T}}=$ NBRC $\left.107691^{\mathrm{T}}\right)$, was isolated from the rhizosphere of Chinese cabbage (Brassica campestris L.).

\section{Acknowledgements}

This study was supported by the National Academy of Agricultural Science (project no. 200901FHT020609339), Rural Development Administration, Republic of Korea.

\section{References}

Breznak, J. A. \& Costilow, R. N. (1994). Physicochemical factors in growth. In Methods for General and Molecular Bacteriology, pp. 137154. Edited by P. Gerhardt, R. G. E. Murray, W. A. Wood \& N. R. Krieg. Washington, DC: American Society for Microbiology.

Chun, J., Lee, J. H., Jung, Y., Kim, M., Kim, S., Kim, B. K. \& Lim, Y. W. (2007). EzTaxon: a web-based tool for the identification of prokaryotes based on $16 \mathrm{~S}$ ribosomal RNA gene sequences. Int J Syst Evol Microbiol 57, 2259-2261.

Fautz, E. \& Reichenbach, H. (1980). A simple test for flexirubin-type pigments. FEMS Microbiol Lett 8, 87-91.

Felsenstein, J. (1985). Confidence limits on phylogenies: an approach using the bootstrap. Evolution 39, 783-791.

Fitch, W. M. (1971). Toward defining the course of evolution: minimum change for a specific tree topology. Syst Zool 20, 406-416.

Gallego, V., García, M. T. \& Ventosa, A. (2006). Pedobacter aquatilis sp. nov., isolated from drinking water, and emended description of the genus Pedobacter. Int J Syst Evol Microbiol 56, 1853-1858.

Gordon, N. S., Valenzuela, A., Adams, S. M., Ramsey, P. W., Pollock, J. L., Holben, W. E. \& Gannon, J. E. (2009). Pedobacter nyackensis sp. nov., Pedobacter alluvionis sp. nov. and Pedobacter borealis sp. nov., isolated from Montana flood-plain sediment and forest soil. Int J Syst Evol Microbiol 59, 1720-1726.

Groth, I., Schumann, P., Weiss, N., Martin, K. \& Rainey, F. A. (1996). Agrococcus jenensis gen. nov., sp. nov., a new genus of actinomycetes with diaminobutyric acid in the cell wall. Int J Syst Bacteriol 46, 234 239.

Hiraishi, A. (1992). Direct automated sequencing of $16 \mathrm{~S}$ rDNA amplified by polymerase chain reaction from bacterial cultures without DNA purification. Lett Appl Microbiol 15, 210-213.

Hwang, C. Y., Choi, D. H. \& Cho, B. C. (2006). Pedobacter roseus sp. nov., isolated from a hypertrophic pond, and emended description of the genus Pedobacter. Int J Syst Evol Microbiol 56, 1831-1836.

Joubert, J. J., van Rensburg, E. J. \& Pitout, M. J. (1984). A plate method for demonstrating the breakdown of heparin and chondroitin sulfate by bacteria. Microbiol Methods 2, 197-202.
Kersters, K., Hinz, K.-H., Hertle, A., Segers, P., Lievens, A., Siegmann, O. \& De Ley, J. (1984). Bordetella avium sp. nov. isolated from the respiratory tracts of turkeys and other birds. Int $J$ Syst Bacteriol 34, 56-70.

Kwon, S. W., Kim, J. S., Park, I. C., Yoon, S. H., Park, D. H., Lim, C. K. \& Go, S. J. (2003). Pseudomonas koreensis sp. nov., Pseudomonas umsongensis sp. nov. and Pseudomonas jinjuensis sp. nov., novel species from farm soils in Korea. Int J Syst Evol Microbiol 53, 21-27.

Kwon, S. W., Kim, B. Y., Lee, K. H., Jang, K. Y., Seok, S. J., Kwon, J. S., Kim, W. G. \& Weon, H. Y. (2007). Pedobacter suwonensis sp. nov., isolated from the rhizosphere of Chinese cabbage (Brassica campestris). Int J Syst Evol Microbiol 57, 480-484.

Margesin, R., Spröer, C., Schumann, P. \& Schinner, F. (2003). Pedobacter cryoconitis sp. nov., a facultative psychrophile from alpine glacier cryoconite. Int J Syst Evol Microbiol 53, 1291-1296.

Mesbah, M., Premachandran, U. \& Whitman, W. B. (1989). Precise measurement of the $\mathrm{G}+\mathrm{C}$ content of deoxyribonucleic acid by highperformance liquid chromatography. Int J Syst Bacteriol 39, 159-167.

MIDI (1999). Sherlock Microbial Identification System, Operating Manual, Version 3.0. Newark, DE: MIDI, Inc.

Roh, S. W., Quan, Z.-X., Nam, Y.-D., Chang, H.-W., Kim, K.-H., Kim, M.-K., Im, W.-T., Jin, L., Kim, S.-H. \& other authors (2008). Pedobacter agri sp. nov., from soil. Int J Syst Evol Microbiol 58, 1640-1643.

Saitou, N. \& Nei, M. (1987). The neighbor-joining method: a new method for reconstructing phylogenetic trees. Mol Biol Evol 4, 406425 .

Seldin, L. \& Dubnau, D. (1985). Deoxyribonucleic acid homology among Bacillus polymyxa, Bacillus macerans, Bacillus azotofixans, and other nitrogen-fixing Bacillus strains. Int J Syst Bacteriol 35, 151-154.

Skerman, V. B. D. (1967). A Guide to the Identification of the Genera of Bacteria, 2nd edn. Baltimore: Williams \& Wilkins.

Smibert, R. M. \& Krieg, N. R. (1994). Phenotypic characterization. In Methods for General and Molecular Bacteriology, pp. 607-654. Edited by P. Gerhardt, R. G. E. Murray, W. A. Wood \& N. R. Krieg. Washington, DC: American Society for Microbiology.

Steyn, P. L., Segers, P., Vancanneyt, M., Sandra, P., Kersters, K. \& Joubert, J. J. (1998). Classification of heparinolytic bacteria into a new genus, Pedobacter, comprising four species: Pedobacter heparinus comb. nov., Pedobacter piscium comb. nov., Pedobacter africanus sp. nov. and Pedobacter saltans sp. nov. proposal of the family Sphingobacteriaceae fam. nov. Int J Syst Bacteriol 48, 165-177.

Tamura, K., Dudley, J., Nei, M. \& Kumar, S. (2007). MEGA4: molecular evolutionary genetics analysis (MEGA) software version 4.0. Mol Biol Evol 24, 1596-1599.

Thompson, J. D., Higgins, D. G. \& Gibson, T. J. (1994). CLUSTAL W: improving the sensitivity of progressive multiple sequence alignment through sequence weighting, position-specific gap penalties and weight matrix choice. Nucleic Acids Res 22, 4673-4680.

Yoon, J. H., Lee, M. H., Kang, S. J., Park, S. Y. \& Oh, T. K. (2006). Pedobacter sandarakinus sp. nov., isolated from soil. Int J Syst Evol Microbiol 56, 1273-1277.

Yoon, J. H., Kang, S. J. \& Oh, T. K. (2007). Pedobacter terrae sp. nov., isolated from soil. Int J Syst Evol Microbiol 57, 2462-2466. 